\title{
Effect of Modified Atmosphere Packaging on Postharvest Quality of Rambutan cv. Binjai
}

\author{
Elisa Julianti, Ridwansyah, Era Yusraini and Ismed Suhaidi \\ Department of Food Science and Technology, Faculty of Agriculture, University of Sumatera Utara, Medan 20152, Indonesia
}

Received: October 24, 2011 / Published: February 20, 2012.

\begin{abstract}
An experiment on retail film packaging system was conducted to compare the atmospheric composition within sealed packs containing rambutan fruits. This research was done in order to study the effect of packaging films with different permeability on the some of physicochemical properties of rambutan during storage at $10{ }^{\circ} \mathrm{C}$. The films used were $0.090 \mathrm{~mm}$ low density polyethylene (LDPE), $0.040 \mathrm{~mm}$ polyprophylene and $0.057 \mathrm{~mm}$ LDPE compared unwrapped fruits. Fruits were evaluated every 5 days for changes in moisture content, total sugars, vitamin C, hardness and color. Unwrapped rambutan had severe browning after 10 days. Sealed packages especially the LDPE had delayed the development of the browning for 20 days of storage and had the lowest weight loss.
\end{abstract}

Key words: Modified atmosphere packaging, rambutan, plastic film, postharvest.

\section{Introduction}

Rambutan (Nephelium lappaeum Linn.) cv. Binjai is an important economic crop of Indonesia especially in North Sumatera with high export values. Its production fluctuates from 263,000 to 350,000 MT/year, which amounts to only $3.5 \%$ of the total fruit production. Indonesia exports its rambutan to the United Arab Emirate, the Netherlands, Saudi Arabia, Taiwan, Singapore, Germany, France and the Philippines [1].

Rambutan has been classified as a non-climacteric fruit $[2,3]$ and has a short shelf life. After harvest, at room temperature condition, the fresh quality of rambutan fruits can be retained for only 3-4 days, and then the spinterns turn brown and ultimately black [4]. The deterioration generally is associated with a decline in appearance, due to skin desiccation and browning water loss. Skin desiccation and browning can be largely minimized by storing rambutans under high relative humidity $(\mathrm{RH})$ and low temperature $[5,6]$.

Corresponding author: Elisa Julianti, lecturer, researcher, research field: postharvest technology. E-mail: elizayulianti@yahoo.com, elisa1@usu.ac.id.
Lam and Kosiyachinda [4] reported that the optimum storage temperature of rambutan was about $12{ }^{\circ} \mathrm{C}$, which can maintain its quality for one week.

The shelf life of many fruits and vegetables has been extended by slowing ripening using polyethylene packaging. Carbon dioxide and oxygen levels within the package are altered with time because of respiration and film permeability. This method is known as modified atmosphere packaging (MAP) [7]. Modified atmospheres can improve the retention of flavor depending on the commodity [8]. MAP reduces $\mathrm{O}_{2}$ levels and increases of $\mathrm{CO}_{2}$ concentrations around the fruit inside the film thereby maintaining the quality of produce at a specific cold temperature [9-12].

The selection of appropriate film for each commodity is an essential factor, since very high $\mathrm{CO}_{2}$ concentration and/or low $\mathrm{O}_{2}$ concentration can induce physiological damage and anaerobic metabolism which adversely affect fruit quality [13, 14]. Mohamed and Othman [15] reported that low temperature storage at $8{ }^{\circ} \mathrm{C}$ prolonged the shelf life of fresh unwrapped rambutans to 6 days, and low permeability packaging 
(polyethylene rigid containers) together with low temperature storage extended the shelf life further to 18 days. Luckanatinwong [16] reported that packaging of rambutans in polyethylene (PE) bags $(70 \mu \mathrm{m}$ thick) under $5 \% \mathrm{CO}_{2}, 5 \% \mathrm{O}_{2}$, and $90 \% \mathrm{~N}_{2}$ and stored at $10{ }^{\circ} \mathrm{C}$ could extend the shelf life for 23 days.

The research was carried out to test the effect of packaging films with different permeability properties on the physiochemical properties of rambutan $c v$. Binjai during storage at $10{ }^{\circ} \mathrm{C}$.

\section{Materials and Methods}

Rambutan $c v$. Binjai used in the study were purchased from a farmer in Binjai, North Sumatera province. Rambutan were harvested at the red maturity. They were transported by car to the laboratory within 3 hours after harvest at temperature $28{ }^{\circ} \mathrm{C}$. They were kept at $10{ }^{\circ} \mathrm{C}$ under ambient air for $12 \mathrm{~h}$ before experiments began, and then were selected to uniformity of size, color and weight. No pre and postharvest chemicals or fungicides were applied. About \pm 300 g (10-12 fruits) of rambutan were randomly placed in individual tray foam and wrapped by either non-perforated low density polyethylene films (LDPE) (Tekpak, Indonesia) of $0.090 \mathrm{~mm}$ and $0.057 \mathrm{~mm}$ or $0.040 \mathrm{~mm}$ Polyprophylene (PP) (Tekpak, Indonesia), and unwrappped fruits as control. The permeability of plastic film at $25^{\circ} \mathrm{C}$ to $\mathrm{CO}_{2}$ and $\mathrm{O}_{2}$ were 1,002 and 3,600, 229 and 656, 4143 and 6226 ml.mil. $\mathrm{m}^{-2} \mathrm{hr}^{-1} \mathrm{~atm}^{-1}$ for $0.090 \mathrm{~mm}$ LDPE, $0.040 \mathrm{~mm}$ PP and $0.057 \mathrm{~mm}$ LDPE respectively. All treatments were stored at $10 \pm 1{ }^{\circ} \mathrm{C}$, for 20 days. Rambutan quality evaluations were performed after storage and included weight loss, moisture content, vitamin $\mathrm{C}$, total sugar, soluble solids content (SSC) and color. Visual appearance evaluated were color, aroma, taste and overall appearance.

\subsection{Weight Loss}

Weight loss was calculated using a balance with an accuracy of $0.01 \mathrm{~g}$ (Sartorius model TE214 S, Germany) and expressed in percentage of fresh weight.

\subsection{Vitamin C Content}

Vitamin $\mathrm{C}$ content was determined in fruit juice by using the iodine titrimetry method described by Ranganna [17]. The results were calculated as mg per $100 \mathrm{~g}$ fresh weight.

\subsection{Total Sugar}

Total sugar was determined by using anthrone method described by Laurentine and Edwards [18]. Results were expressed as percentage of fresh weight.

\subsection{Soluble Solid Content (SSC)}

Soluble solid content (SSC) was determined by placing a drop of juice on the prism of hand refractometer and expressed as ${ }^{\circ}$ brix (RHB-32 ATC) at $25^{\circ} \mathrm{C}[17]$.

\subsection{Titratable Acidity Percentage}

Titratable Acidity Percentage was determined by taking an aliquot of the sample $(10 \mathrm{~mL})$ with distilled water $(40 \mathrm{~mL})$ and titrated with $0.01 \mathrm{~N} \mathrm{NaOH}$ using phenolphtalein solution as an indicator. The titer value was noted and acidity was calculated using the standard formula [17]. The results were expressed as percentage anhydrous citric acid.

\subsection{Fruit Firmness}

Fruit firmness was determined by using a fruit hardness tester and the results were expressed as g.

\subsection{Visual Appearance}

Visual appearance was included color, aroma, taste and overall appearance using 5-point hedonic scale and was conducted by 15 semi-experienced panelists.

\subsection{Changes in Gases Composition Within Packages}

Changes in gases composition within packages were measured as follows: The concentration of carbon dioxide and oxygen within the packed units were measured by using a thermal conductivitymeter (cosmotector type XPO 318 for oxygen and XP 314 for carbon dioxide, New Cosmos Electric Co. Osaka, Japan). 


\subsection{Statistical Analysis}

All data for each parameter were analyzed as Factorial Completely Randomized Design in factorial arrangement with three replications. Data were statistically analyzed by the analysis of variance (ANOVA), and means were compared by the Tukey Test at a significance level of 0.05 using Minitab 14 software.

\section{Results and Discussion}

\subsection{Changes in Gas Composition within Packages}

Concentration of oxygen in packs wrapped with permiable films decreased (Fig. 1) and that of carbon dioxide increased during $36 \mathrm{hr}$ of storage (Fig. 2), after which a state of equilibrium was reached between respiration of produce and the difussion of these gases was counter balanced by production and consumption during respiration of the rambutans [19] and no further changes in the gas concentration within the packs occured with fruit kept at constant temperature [20]. The $0.090 \mathrm{~mm}$ LDPE films had comparatively lower concentration of $\mathrm{O}_{2}(18.2 \%)$ and higher concentration of $\mathrm{CO}_{2}(3.0 \%)$ in MAP than the $0.057 \mathrm{~mm} \mathrm{LDPE}$ $\left(20.3 \% \mathrm{O}_{2}\right.$ and $\left.1.6 \% \mathrm{CO}_{2}\right)$ and $0.040 \mathrm{~mm} \mathrm{PP}\left(20.4 \% \mathrm{O}_{2}\right.$

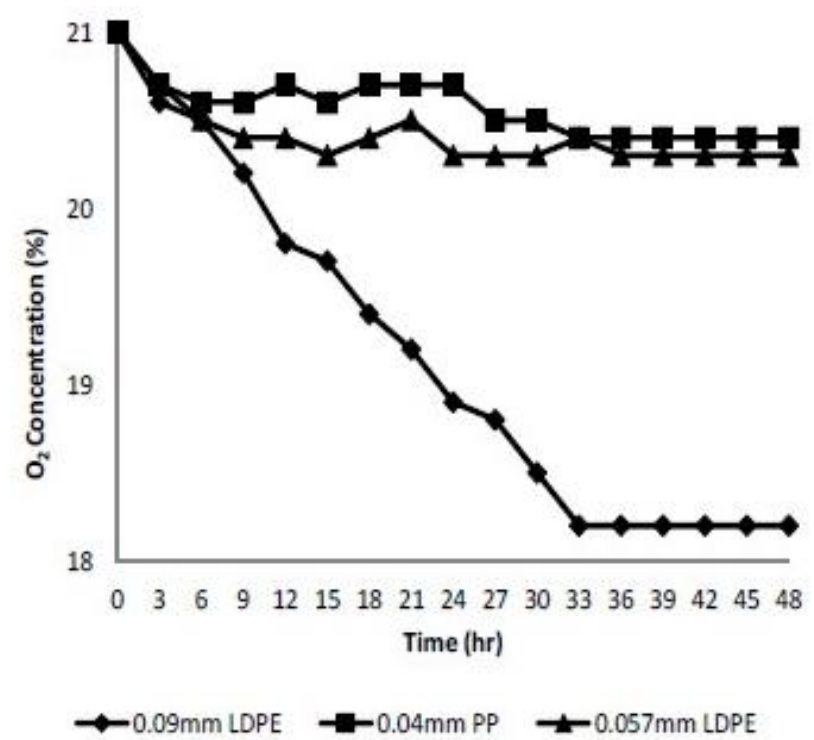

Fig. 1 Changes in $\mathrm{O}_{2}$ concentrations in MAP-stored "Rambutan cv. Binjai" at $10{ }^{\circ} \mathrm{C}$. Value means of 3 replicates. and $1.8 \% \mathrm{CO}_{2}$ ). The steady levels of $\mathrm{O}_{2}$ and $\mathrm{CO}_{2}$ inside the package within $36 \mathrm{hr}$ were $18 \%-20 \%$ and $1 \%-3 \%$ respectively and they were less than that previously reported. According to Kader [21] the recommended condition for storage and transportation of rambutan fruits was $7 \%$ to $12 \%$ of $\mathrm{CO}_{2}$ and $3 \%$ to $5 \%$ of $\mathrm{O}_{2}$ at $10{ }^{\circ} \mathrm{C}$, and O'Hare et al. [5] reported that 9 to $12 \%$ of $\mathrm{CO}_{2}$ retained color and extended shelf life of rambutans for 4 to 5 days. But the steady levels of $\mathrm{CO}_{2}$ and $\mathrm{O}_{2}$ in these packages could cause marked changes in the activities of specific enzymes in the respiratory metabolism and might have uncoupling effect on oxidative phosphorylation [7]. This might have led to the extension of shelf life of rambutan in MAP at $10^{\circ} \mathrm{C}$ for more than 20 days as compared to 15 days in unwrapped control.

\subsection{Weight Loss}

Changes in weight loss of rambutans in different packaging systems during storage are shown in Fig. 3 . Weight loss of Rambutan $c v$. Binjai increased during ambient and cold storage. However, MAP significantly $(P<0.05)$ inhibited weight loss compared to control fruits. Among the various types of packaging, the 0.090 mm LDPE showed the lowest weight loss of about

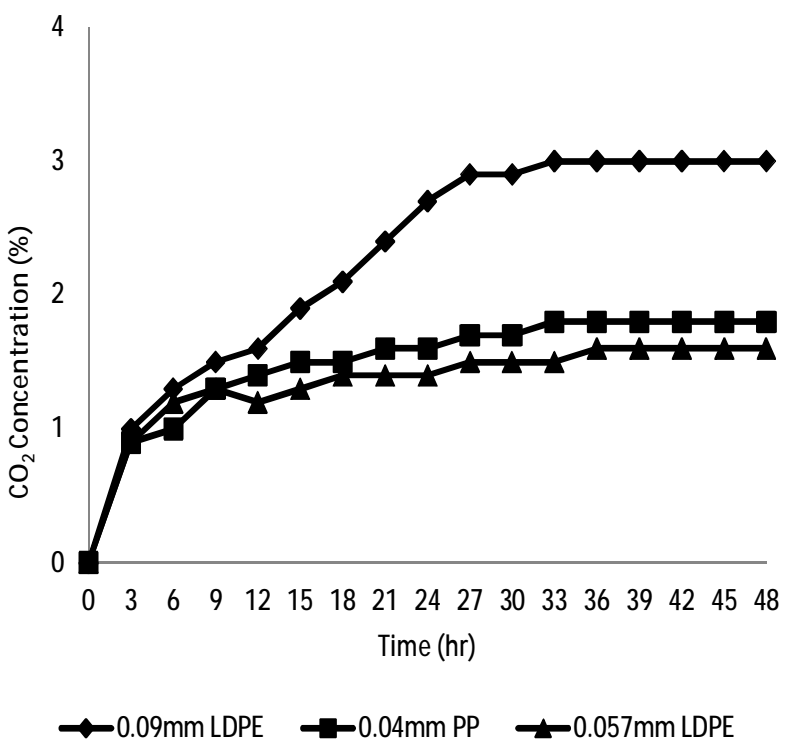

Fig. 2 Changes in $\mathrm{CO}_{2}$ concentrations in MAP-stored "Rambutan $c v$. Binjai" at $10{ }^{\circ} \mathrm{C}$. Value means of 3 replicates. 


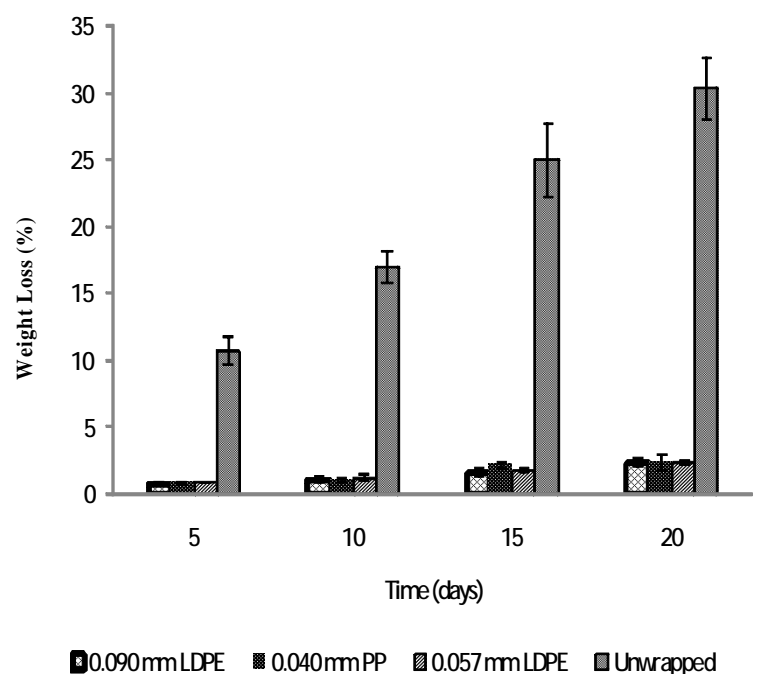

Fig. 3 Changes in weight loss of Rambutan $c v$. Binjai in different packaging materials and unwrapped fruits stored at $10{ }^{\circ} \mathrm{C}$ during the storage period. Vertical bars represent SE of means.

$2.38 \%$, followed by $0.040 \mathrm{PP}(2.40 \%), 0.057 \mathrm{~mm}$ LDPE (2.45\%) and control (unwrapped fruits, 30.48\%) at 20 days of storage (Fig. 3). Weight loss of rambutans without packaging films increased rapidly during storage, which was associated with severe spintern browning due to water loss [22, 23]. Modified atmosphere packaging was shown can reduce water loss from rambutans as shown in Fig. 4. Rambutans packaged in $0.09 \mathrm{~mm}$ LDPE had higher moisture content $(73.19 \%)$ than $0.040 \mathrm{~mm}$ PP $(70.86 \%), 0.057$ mm LDPE (72.76\%) and unwrapped fruits $(69.84 \%)$ after 20 days of storage (Fig. 4). Water loss occurs because of a water vapor pressure gradient and high relative humidity could be effective in minimizing water loss [21]. Modified atmosphere packaging reduced transpiration and respiration rates of the fruits, hence decreasing water loss [24].

\subsection{Changes in Sugar and Organic Acid}

In all treatments, SSC of rambutans decrease gradually. At 20 days of storage, the $0.090 \mathrm{~mm}$ LDPE had higher SSC value after $0.04 \mathrm{PP}$ and $0.057 \mathrm{~mm}$ LDPE. Lowest SSC during storage was recorded in the unwrapped rambutan as shown in Fig. 5. SSC content is one of the most reliable parameters in judging fruit

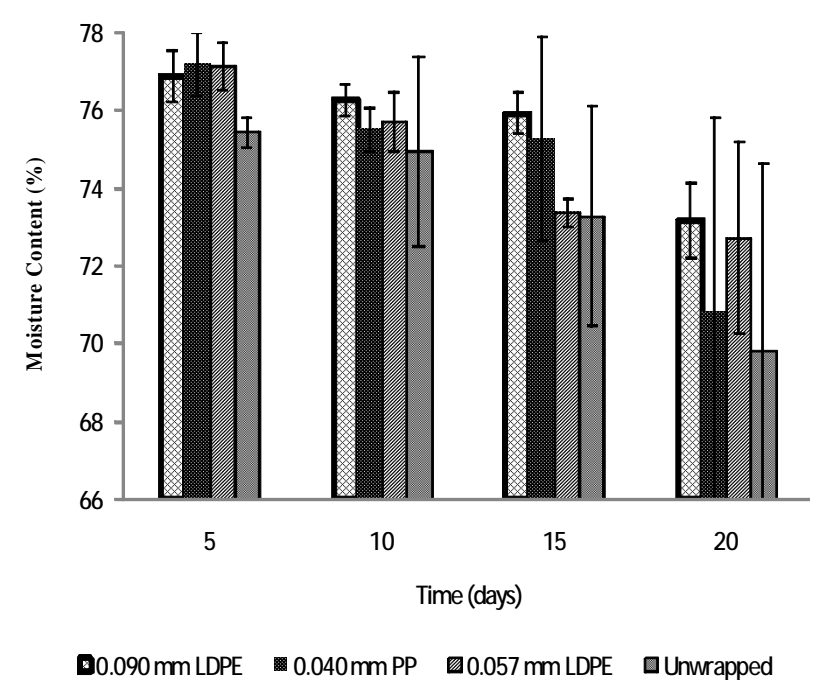

Fig. 4 Changes in moisture content of Rambutan $c v$. Binjai in different packaging materials and unwrapped fruits stored at $10{ }^{\circ} \mathrm{C}$ during the storage period. Vertical bars represent $\mathrm{SE}$ of means.

quality [25]. Quality factors such as SSC, TA and visible quality (e.g. color, size and firmness) are prime considerations of consumers [26, 27]. Numerous studies have shown a decrease in SSC during storage [8, 28].

Total sugars gradually decreased with increasing in storage time (Fig. 6). Modified atmosphere treatments exhibited significantly $(P<0.05)$ higher total sugars compared to unwrapped fruits. At the end of storage, there were no significant difference between all modified atmosphere packages.

Ascorbic acid (vitamin C) of rambutan decreased with the passage of time in all treatments as shown in Fig. 7. Different packaging had shown no significant difference $(P>0.05)$ on ascorbic acid content. Acid content in fruits is known to decrease during storage possibly due to respiration activity of living tissues during which depletion of organic acids takes place [8]. Senescence leads to quality deterioration and losses in Vitamin C [8]. As shown in Fig. 8, total titratable acidity $(\%)$ decreased with the progress in storage period up to 10 days, then increased to the end of storage (20 days). There was no significant difference $(P>0.05)$ among all modified atmosphere packages on titratable acidity of rambutans. 


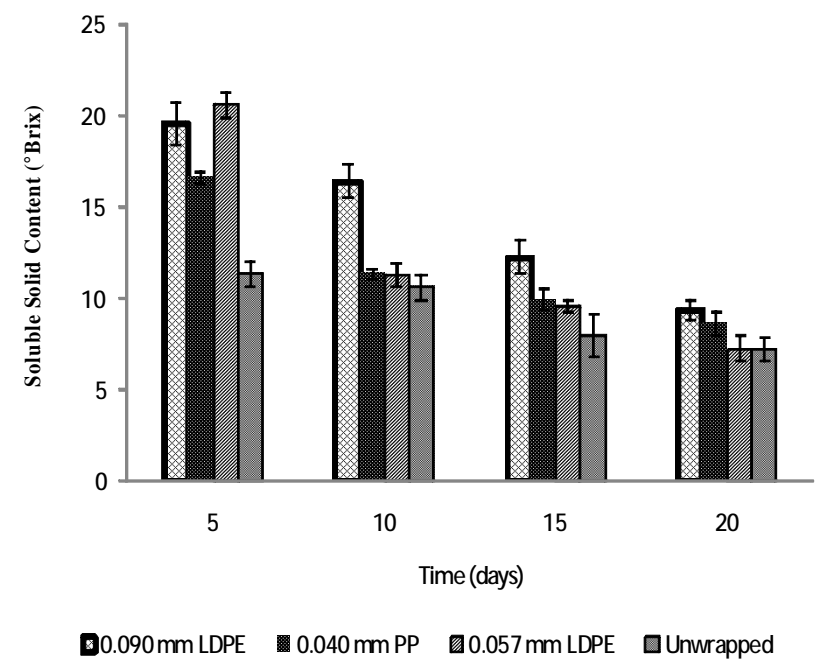

Fig. 5 Changes in SSC of Rambutans cv. Binjai in different packaging materials and unwrapped fruits stored at $10{ }^{\circ} \mathrm{C}$ during the storage period. Vertical bars represent SE of means.

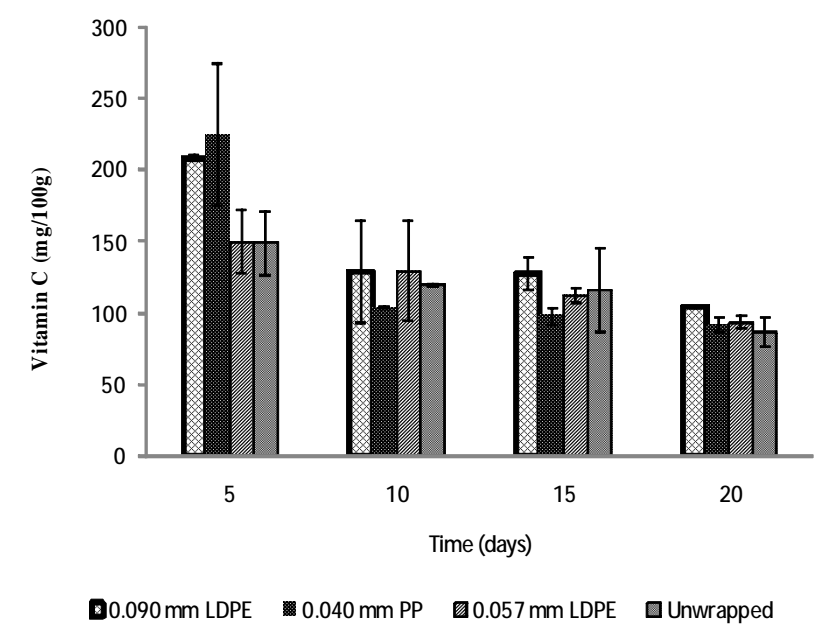

Fig. 7 Changes in vitamin $\mathrm{C}$ of Rambutan $c v$. Binjai in different packaging materials and unwrapped fruits stored at $10^{\circ} \mathrm{C}$. Vertical bars represent $\mathrm{SE}$ of means.

Moreover, unwrapped fruit exhibited the highest percentage $(1.01 \%)$ of total acidity after 20 days of storage. Similar results were found by Kelany et al. [29] on "Kent" mango fruits.

\subsection{Fruit Firmness and Color Characteristics}

Firmness changes of fruits stored under different packages are shown in Fig. 9. It is clear from data in Fig. 9 that, all treatments reduced the rate of firmness more than the initial sample. Up to 15 days of storage there was no significant difference $(P>0.05)$ among all

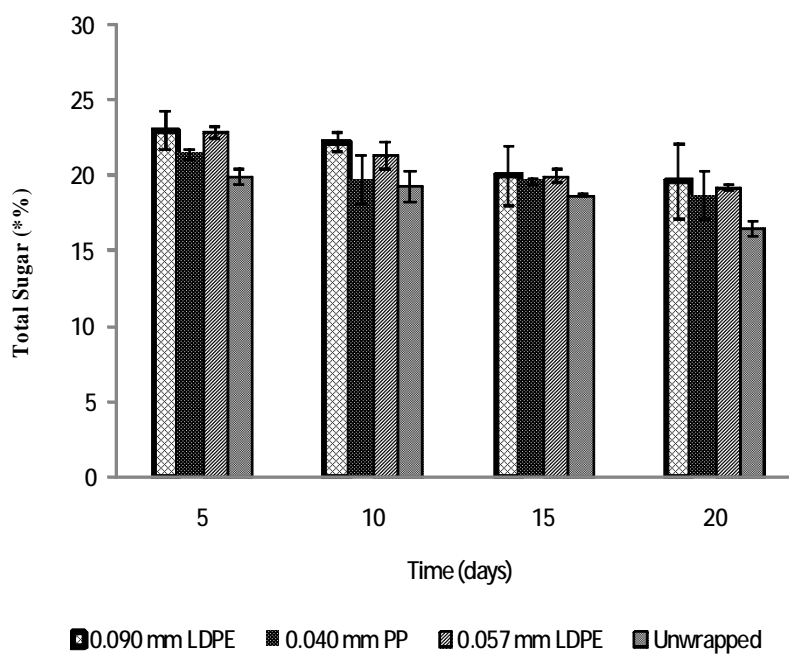

Fig. 6 Changes in total sugar of Rambutans cv. Binjai in different packaging materials and unwrapped fruits stored at $10{ }^{\circ} \mathrm{C}$ during the storage period. Vertical bars represent SE of means.

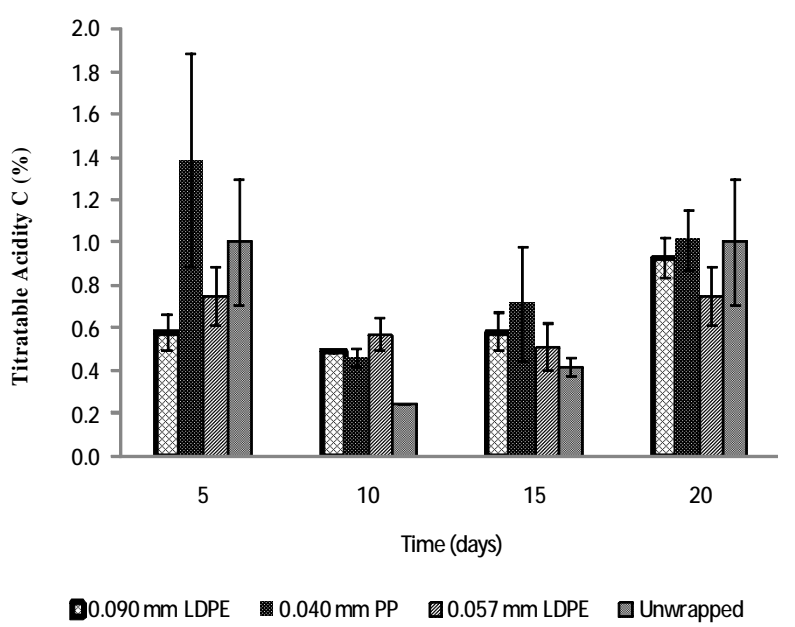

Fig. 8 Changes in titratable acidity of Rambutan $c v$. Binjai in different packaging materials and unwrapped fruits stored at $10^{\circ} \mathrm{C}$. Vertical bars represent SE of means.

treatments, but at the end of storage there was significant difference $(P<0.05)$ between the $0.09 \mathrm{~mm}$ LDPE and the $0.057 \mathrm{~mm} \mathrm{LDPE}, 0.04 \mathrm{~mm}$ PP and unwrapped fruits. During storage of rambutans, dehydration of the skin resulted in decrease in firmness [15].

Changes in color determined by a* value (redness) are shown in Fig. 10. The retention of the red color ( $\mathrm{a}^{*}$ value) was highest under MAP storage especially in the $0.09 \mathrm{~mm}$ LDPE packages. Browning of rambutans was associated with a decrease in $a^{*}$ value. The results showed that $\mathrm{a}^{*}$ value generally decreased during storage 


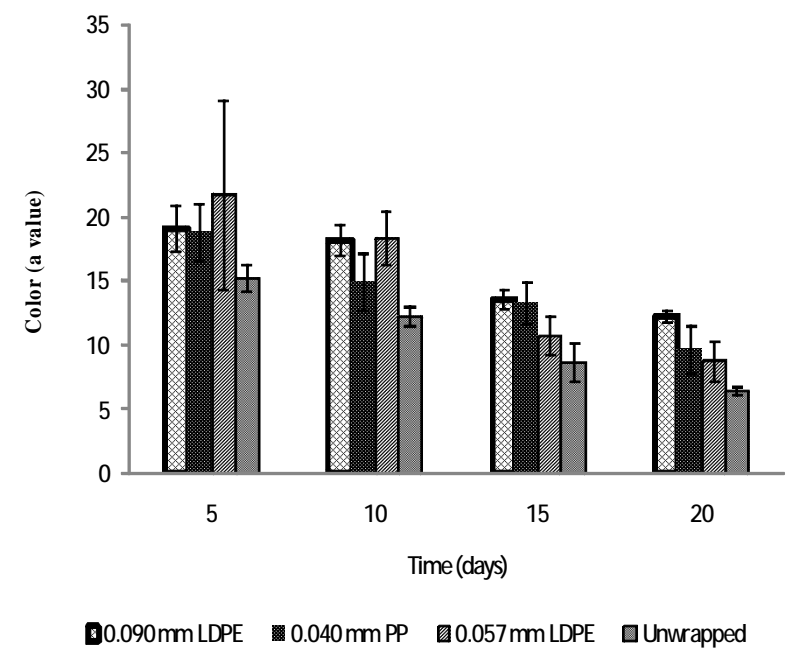

Fig. 9 Changes in firmness of Rambutan cv. Binjai in different packaging materials and unwrapped fruits stored at $10^{\circ} \mathrm{C}$. Vertical bars represent $\mathrm{SE}$ of means.

in all treatments. The lowest $\mathrm{a} *$ value were observed in unwrapped fruits, which had severe browning. Browning was caused by dehydration, which was ascribed to rambutan's morphology as the skin is covered by hair-like protuberances (spinterns) that make rambutans tend to lose water [6]. This water loss induces browning in the rambutan spinterns during storage. This type of browning that was shown is a limiting factor of rambutans quality. All treatments were deteriorated due to spintern browning.

\subsection{Sensory Quality}

Sensory quality (color, aroma, taste and overall acceptance) of MAP rambutans after 20 days at cold storage was better than the unwrapped one (Table 1). The taste of rambutans was still accepted by panelist up to 20 days of storage although their color had been rejected.

\section{Conclussion}

Modified atmosphere packaging of $18.2 \% \mathrm{O}_{2}$ and $3 \% \mathrm{CO}_{2}$ at $10{ }^{\circ} \mathrm{C}$ with $0.09 \mathrm{~mm} \mathrm{LDPE}$ was effective for storage of Rambutan $c v$. Binjai, keeping its overall quality, mainly by delaying spintern browning, the main factor affecting quality of rambutan. The types of plastic film used affected the gaseous atmosphere around the fruit and the quality of fruits, and therefore

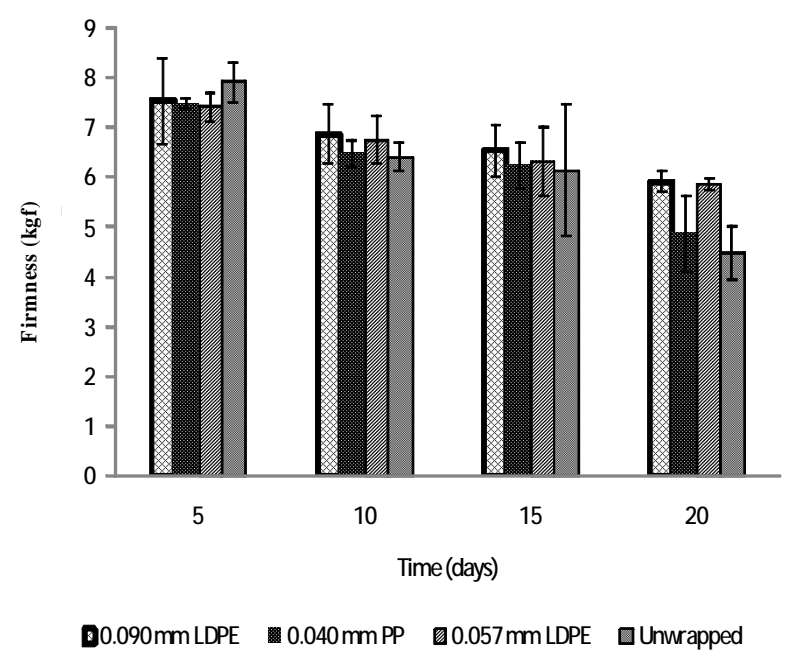

Fig. 10 Changes in color (a values) of Rambutan $c v$. Binjai in different packaging materials and unwrapped fruits stored at $10^{\circ} \mathrm{C}$. Vertical bars represent SE of means.

Table 1 Sensory scores for modified atmosphere packaged rambutan $c v$. Binjai at the 20 days of storage.

\begin{tabular}{lllll}
\hline Packages & Color & Aroma & Taste & $\begin{array}{l}\text { Overall } \\
\text { acceptance }\end{array}$ \\
\hline $0.09 \mathrm{~mm}$ LDPE & $3.1^{\mathrm{a}}$ & $3.2^{\mathrm{a}}$ & $3.5^{\mathrm{a}}$ & $3.3^{\mathrm{a}}$ \\
$0.057 \mathrm{~mm} \mathrm{LDPE}$ & $2.9^{\mathrm{b}}$ & $3.0^{\mathrm{b}}$ & $3.2^{\mathrm{b}}$ & $3.1^{\mathrm{a}}$ \\
$0.04 \mathrm{~mm} \mathrm{PP}$ & $2.8^{\mathrm{b}}$ & $2.8^{\mathrm{c}}$ & $3.4^{\mathrm{a}}$ & $3.1^{\mathrm{a}}$ \\
Unwrapped Rambutans & $2.1^{\mathrm{c}}$ & $2.5^{\mathrm{d}}$ & $3.1^{\mathrm{b}}$ & $2.7^{\mathrm{b}}$ \\
\hline
\end{tabular}

Hedonic scale for color, aroma, taste and overall aceptance : 1 = low, $2=$ moderate, $3=$ moderate to high, $4=\operatorname{good} / \mathrm{high}, 5=$ very good/very high.

a,b,c,d The same letter within columns are not significantly different at $P<0.05$ (Tukey Test).

their maximum storage life. Rambutan fruits $c v$. Binjai packaged in $0.09 \mathrm{~mm}$ LDPE had a postharvest life of 20 days at $10{ }^{\circ} \mathrm{C}$, but under the similar conditions, the postharvest life of unwrapped fruit was 10 days.

\section{Acknowledgment}

Authors are grateful to Director General of Higher Education, Ministry of National Education Republic of Indonesia for funding this research through "Hibah Kompetensi" Project.

\section{References}

[1] R. Poerwanto, Rambutan and longan production in Indonesia, Acta Hort. [Online], 665 (2005) 81-86, http://www.actahort.org/books/665/665_9.htm.

[2] T.J. O'Hare, Postharvest physiology and storage of rambutan, Postharvest Biology and Technology 6 (1995) 
189-199.

[3] J. Siripanich, Postharvest Physiological of Fruits and Vegetables, 4th ed., Kasetsart University, Bangkok, 2001, p. 416.

[4] P.F. Lam, S. Kosiyachinda, Rambutan: Fruit Development, Postharvest Physiology and Marketing in ASEAN, ASEAN Food Handling Bureau, Malaysia, 1987.

[5] T.J. O'Hare, A. Prasad, A.W. Cooke, Low temperature and controlled atmosphere storage of rambutan, Postharvest Biology and Technology 4 (1994) 147-157.

[6] M. Landrigan, Postharvest browning of rambutan (Nephelium lappaceum L.), Ph.D. Thesis, University of Western Sydney, Hawkesbury, Australia, 1996.

[7] A.A. Kader, Biochemical and physiological basis for effects of controlled and modified atmospheres on fruits and vegetables, Food Technology 5 (1986) 99-104.

[8] R.B.H. Wills, T.H. Lee, P. Graham, W.B. McGlasson, E.G. Hall, Post Harvest: An Introduction to The Physiology and Handling of Fruits and Vegetables, New South Wales University Press, Australia, 1982,

[9] V.B. Rodov, Y. Vinokur, A. Copel, Y. Aharoni, N. Aharoni, Modified atmosphere packaging improves keeping quality of Charentais-type melons, HortScience 37 (2002) 950-953.

[10] C.K. Ding, K. Chachin, Y. Ueda, Y. Imahori, C.Y. Wang, Modified atmosphere packaging maintains postharverst biology \& technol, Postharvest Biol. \& Technol. 24 (2002) 341-348.

[11] C.K. Illeperuma, P. Jayasuriya, Prolonged storage of "Karuthacolomban" mango by modified atmosphere packaging at low temperature, J. Hort. Sci. \& Biotechnol. 77 (2002) 153-157.

[12] D. Zagory, A.A. Kader, Modified atmosphere packaging of fresh produce, Food Technology 42 (9) (1988) 70-77.

[13] A.A. Kader, Biological bases of $\mathrm{O}_{2}$ and $\mathrm{CO}_{2}$ effects on postharvest life of horticultural perishables, in: M.E. Saltveit (Ed.), Proc. 7th Intl. Controlled Atmosphere Res. Conf., Vegetables and Ornamentals, Univ. Calif. Postharvest Hort. Ser., Vol. 4, 1997, pp. 160-163.

[14] A.A. Kader, C.B. Watkins, Modified atmosphere packaging toward 2000 and beyond, Hort. Technol. 10 (3) (2000) 483-486.

[15] S. Mohamed, E. Othman, Effect of packaging and modified atmosphere on the shelf life of rambutan (Nephelium lappaceum) I, Pertanika 11 (1988) 217-228.

[16] V. Luckanatinwong, Modified atmosphere storage of rambutan for export, J. of Sci. and Tech. (Thammasat University) 13 (2005) 6-34.
[17] S. Ranganna, Handbook of Analysis and Quality Control for Fruit and Vegetable Products, $2^{\text {nd }}$ ed., McGraw Hill Publishing Co. Ltd, New Delhi, 1999.

[18] A. Laurentin, C.A. Edwards, A microtiter modification of the anthronesulfuric acid colorimetric assay for glucose-based carbohydrates, Analytical Biochemistry 315 (2003) 143-145.

[19] J.D. Geeson, K.M. Browne, New packaging technology aims to extend shelf Life, Grower 14 (1983) 35-38.

[20] A.A. Kader, Modified atmosphere during transport and storage, in: A.A. Kader (Ed.), Postharvest Technology of Horticultural Crops, University of California, Publication 3311, USA, 1992, pp. 85-92.

[21] A.A. Kader, Modified and controlled atmosphere storage of tropical fruits, in: B.R. Champ, E. Highley, G.I. Johnson (Eds.), Postharvest Handling of Tropical Fruits, Proc. Intern. Confer. Chiang Mai, Thailand, ACIAR Pub. No. 50, 1993, pp. 239-249.

[22] S.K. Lee, P.C. Leong, Storage Studies on Rambutan in Singapore, Workshop on Mango and Rambutan, University of Philippines, Los Banos, 1982, pp. 172-175.

[23] P.F. Lam, K.H. Ng, Storage of waxed and unwaxed rambutan in perforated and sealed polyethylene bags, Food Technology Division: Report Number 251, Malaysia Agricultural Research and Development Institute, Serdang, Selangor, 1982.

[24] S.C. Fonseca, F.A.R. Oliveira, I.B.M. Lino, J. Brecht, K.V. Chau, Modelling $\mathrm{O}_{2}$ and $\mathrm{CO}_{2}$ exchange for development of perforation-mediated modified atmosphere packaging, $\mathrm{J}$. of Food Eng. 43 (2000) 9-15.

[25] R. Lu, Multispectral imaging for predicting firmness and soluble solids content of apple fruit, Postharvest Biol. and Technol. 31 (2004) 147-157.

[26] J.E. Manzano, Y. Perez, E. Rojas, Coating waxes on Haden mango fruits (Mangifera indica L.) cultivar for export, Acta Hort. 455 (1997) 738-746.

[27] F.S. Kittur, N. Saroja, R.N. Tharanathan, Polysaccharide-based composite coatings formulation for shelf life extension of fresh banana and mango, Eur. Food Red. Tec. 213 (2001) 306-311.

[28] A.A. Kader, Post Harvest Biology and Technology: An Overview, Post harvest Technology of Horticultural Crops, Cooperation Extension University of California, Division of Agriculture and Natural Resources, 1985.

[29] A.E. Kelany, S.M. Abdel-Wahab, A.A. Abdel-Hafez, M.T. Osman, Using modified atmosphere and different temperature for storing "Kent" mango fruit, J. of Hort. Sci. \& Ornamental Plants 2 (1) (2010) 45-56. 